\title{
Effects of Input-based and Output-based Instructions on Iranian EFL Learners' Productive Knowledge of Collocations
}

\author{
Nawal Gholami \\ Department of English Language Teaching, Khouzestan Science and Research Branch, Islamic Azad University, Ahvaz, Iran \\ Department of English Language Teaching, Ahvaz Branch, Islamic Azad University, Ahvaz, Iran \\ Mohammad Taghi Farvardin (Corresponding author) \\ Department of English Language Teaching, Ahvaz Branch, Islamic Azad University, Ahvaz, Iran \\ E-mail: farvardin@iauahvaz.ac.ir
}

Received: 19-11-2016

Published: 01-05-2017
Accepted: 12-01-2017

doi:10.7575/aiac.ijalel.v.6n.3p.123
Advance Access Published: March 2017

URL: http://dx.doi.org/10.7575/aiac.ijalel.v.6n.3p.123

\begin{abstract}
Few studies have investigated the effects of input-based and output-based instructions on collocational knowledge of EFL learners. Therefore, this study aimed to examine the effects of these instructional approaches on Iranian EFL learners' productive knowledge of collocations. To this end, 80 senior high school students from three intact classes at Tali-e High School in Ahvaz, Iran, were selected. Each class was assigned to a control group $(n=28)$ and two experimental groups including the input group $(n=27)$ and the output group $(n=25)$. Twenty collocations were selected as the target collocations. Then, a pretest was administered to all groups. Two days after the last treatment session, an immediate posttest was given to the participants. A delayed posttest was also administered two weeks later. The results of Mixed-ANOVA, one-way ANOVA, and Tukey post hoc tests revealed that both input and output groups outperformed the control group on the immediate and delayed posttests. However, there were no significant differences between the input and output groups on the posttests. The implications and suggestions for future research are also presented.
\end{abstract}

Keywords: input-based instruction, output-based instruction, productive knowledge, collocations, EFL learners

\section{Introduction}

It has been argued that knowing collocations is essential for learning a second/foreign language (McCarthy \& O'Dell, 2006). Collocation is defined as "a group of words that occurs repeatedly in a language" (Benson, 1985, p. 61). It has been proposed that such language patterns comprise much of speech and writing (Lewis, 2000). Therefore, learning words in chunks can improve fluency in writing and speaking (Hill, 2000).

There are different types of lexical collocations, such as noun + noun (e.g., washing machine), adjective + noun (e.g., hardened criminal), verb + noun (e.g., shrunk shoulder), noun + verb (e.g., brake screen), and adverb + verb (e.g., totally unaware) (Milton, 2009). Collocational knowledge has been also classified into receptive and productive knowledge (Milton, 2009). Receptive knowledge means collocations that can be distinguished during listening or reading, while productive knowledge refers to using collocations in speech and writing.

Since the 1990s, the attention of second language (L2) researchers has directed from traditional techniques to those that encourage learners to notice more to target forms of an L2 (Shintani, 2015). In line with this shift of focus, Smith (1991), first, proposed consciousness-raising (CR) theory indicating a deliberate focus on the formal aspects of language in order to facilitate the development of target language knowledge. Following CR theory, some scholars attempted to develop techniques with the aim of promoting L2 learners' noticing (Smith, 1991; White, 1998).

One of such techniques is called input-based instruction which "involves the manipulation of the input that learners are exposed to or are required to process" (Ellis, 2012, p. 285). Textual enhancement (TE) and input flood (IF) are two forms of input-based instruction (Moradi \& Farvardin, 2016). It has been argued that TE techniques (e.g., underlining, italicizing, and bold facing) can increase the input saliency leading learners to raise their awareness toward input (Schmidt, 2001). The other input-based instruction technique is IF which intends to enhance L2 learning through repeated exposure to the L2 target words or structures (Reinders \& Ellis, 2009).

On the other hand, some scholars (e.g., Swain, 2005; Toth, 2006) have considered a more pivotal role for the outputbased instruction. The output-based instruction is greatly influenced by Swain's $(1995,2000)$ output hypothesis in which she proposes three functions of output. The first function is noticing function which states that in the production of a target language, "learners may notice a gap between what they want to say and what they can say, leading them to recognize what they do not know, or know only partially" (Swain, 1995, pp. 125-126). The recognizing of language problems may enhance learners to present to the associated information in the following input process (Swain \& 
Lapkin, 1995). In brief, the noticing function of output helps enhancing learners' interlanguage knowledge. The second function is hypothesis-testing function which argues that language production enables learners to test their hypothesis of interlanguage through which learners can decide and judge about the comprehensibility and correctness of their output against feedback given by teacher. This process of modification can lead to language acquisition since learners are involved in "cognitive processes that have been implicated in second language learning" (Swain, 1995, p. 130) while they are doing modification. The third function is metalinguistic function which asserts that "as learners reflect upon their own target language use, their output serves a metalinguistic function, enabling them to control and internalize linguistic knowledge" (Swain, 1995, p. 126).

The role of input-based and output-based instructions in L2 teaching has been a controversial issue. Moreover, the effect of input-based instruction on L2 learners' collocational knowledge needs to be compared with that of outputbased instruction to obtain a clearer picture of the effectiveness of these instructional approaches in L2 learning. To fill in the existing gap, this study aimed to investigate the effects of input-based instruction techniques (i.e., TE and IF), and output-based instruction on Iranian EFL learners' collocational knowledge.

There have been some empirical studies focusing on the learning of collocations in a second/foreign language (e.g., Asaei \& Rezvani, 2015; Fahim \& Vaezi, 2011; Szudarski \& Carter, 2016). Fahim and Vaezi (2011) examined the effect of TE on learning the verb-noun lexical collocations. The participants were 96 Iranian intermediate learners. They were randomly assigned to three equal groups. After the pretest, all groups received 10 sessions of instruction constructed of 10 English passages. One experimental group received English passages with bolded or capitalized collocations. The other experimental group received a conventional treatment, and the control group received no treatment. Afterwards, all groups took a posttest. The results showed that there was a significant difference $(p<.05)$ in the scores obtained from the pre and posttest. The results also indicated that both visually enhanced input and conventional treatment had significant effects on learning L2 collocations.

In another study, Asaei and Rezvani (2015) examined the effect of explicit and implicit instructions on Iranian EFL learners' use of collocations in L2 writing. To this end, 45 adult Iranian EFL learners were selected from three intact classes. Two classes were assigned to the experimental groups, and the third class was assigned to the control group. The participants in the explicit group were taught the English collocations through repetition, memorization and translation. The participants in the implicit group were taught the target collocations through typographical techniques (i.e., bolding and underlining). The participants in the control group were asked to read the passages and answer some reading comprehension questions about the passages. A pretest was given to measure the participants' use of collocation in a written form. It contained 20 selected collocations. After the treatment, the participants were given the 20 target words to write a complete sentence for each. The results of ANOVA revealed that the three groups differed significantly in terms of their mean scores on the posttest $(p<.05)$. The results also showed that the explicit group scored significantly higher than the other two groups in using L2 collocations.

Recently, Szudarski and Carter (2016) compared the effect of two techniques (i.e., IF only and IF plus TE) on the L2 collocation learning in an EFL environment. To this end, 41 students of English in Poland attended in the study. They were assigned to two experimental groups (13 participants in each group) and one control group (15 participants). To determine the roles of the two treatments, one of the experimental groups (the IF plus TE group) read the stories in group, while the IF group read the same stories, in which target collocations were not highlighted. The control group was also participated just in the pretest and posttest. The result showed that the IF combined with TE group outperformed the IF group.

\subsection{Statement of the Problem and Purpose}

In second/foreign language learning, even advanced learners have difficulty using collocations since in contrast to native speakers, second/foreign language learners use less collocations and hence, they tend to make errors in using collocations (e.g., make homework instead of do homework) (Laufer \& Waldman, 2011). As Nesselhauf (2005) argued, the learners' problems with collocations have not been examined in detail yet. In addition, there are few, if any, studies to compare the effects of input-based and output-based instructions on L2 collocation learning of EFL learners. Motivation behind this study emanates from the paucity of research in this area of the study, especially in Iran. Therefore, the present study aimed to probe the effects of input-based and output-based instructions on productive collocational knowledge of Iranian EFL learners.

\subsection{Research Questions}

To deal with the existing problem in the literature, the present study aimed to answer the following research questions:

Q1: Does input-based instruction significantly affect Iranian EFL learners' productive knowledge of collocations?

Q2: Does output-based instruction significantly affect Iranian EFL learners' productive knowledge of collocations?

Q3: If both instructional approaches significantly affect Iranian EFL learners' productive knowledge of collocations, which one will be more effective? 


\section{Method}

\subsection{Design}

This study adopted a quasi-experimental design including pretest, treatment, and two posttests. The participants received treatment in four sessions during two weeks, beginning one week after the pretest. The immediate posttest was administered after the last treatment session. The delayed posttest was administered two weeks later.

\subsection{Participants}

In this study, 80 senior high school students at Tali-e High School in Ahvaz, Iran, participated. All participants were Persian-speaking females whose age ranged from 17 to 18 . The participants were selected from three intact classes. The participants' proficiency level was lower-intermediate based on their score on the Oxford Placement Test (OPT) (Allan, 2004). OPT consists of 200 items (i.e., 100 grammar and 100 listening items). The band score for lower-intermediate level is 120 to 134. Afterwards, the classes were assigned to a control group $(n=28)$ and two experimental groups including the input group $(n=27)$ and the output group $(n=25)$. The input group received input-based instruction, i.e. IF plus TE techniques; the output group received output-based instruction; whereas the control group received traditional instruction (translating L2 collocations into L1 using an English to Persian dictionary).

\subsection{Instruments}

\subsubsection{Target Collocations}

Thirty collocations were first selected from English Collocations in Use (McCarthy \& O'Dell, 2006). The collocations included noun + noun, adjective + noun, verb + noun, noun $+v e r b$, and adverb + verb structures. Then, a pilot study was administered on 25 senior high school students to make sure that collocations were unknown to the participants. It was revealed the students in the pilot study did not know the meaning of 20 collocations. These collocations were selected as the target collocations. Afterwards, the collocations were presented to the participants in four sessions (Appendix A).

\subsubsection{Productive Collocation Test}

The productive collocation test contained 30 fill-in-the-blank items in which 10 items served as distractors. The format of the test was adapted from Laufer and Nation (1999). The test was the same for all groups (i.e., input, output, and control) in pretest, immediate posttest, and delayed posttest. Each correct answer received 1 point, and the incorrect ones received no point. Therefore, the maximum score was 20 . The reliability of the test was measured through testretest method. The Pearson correlation coefficient between the pretest and immediate posttest was 0.85 . The Pearson correlation coefficient between the pretest and delayed posttest was 0.87 . Moreover, the Pearson correlation coefficient between immediate and delayed posttest was 0.80. The test including the 20 target items is presented in Appendix B.

\subsection{Procedures}

First, a pretest was administered to 80 senior high school students in three intact classes. The pretest was administered to ensure the extent of the participants' L2 collocational knowledge. One week after administering the pretest, each class was randomly assigned to one group, a control group and two experimental groups. Twenty L2 collocations in four passages were used in the treatment. One experimental group received input-based instruction, i.e. input flood plus input enhancement; the second experimental group received output-based instruction. The control group received traditional treatment (translating L2 collocations using dictionary). Both experimental and control groups were taught five collocations each week. Totally, 20 collocations were taught. The instruction lasted for 20 minutes each session. The participants were exposed to the reading passage that contained L2 collocations, and the teacher checked their understanding by asking some questions. In the input group, the teacher presented the students with five L2 collocations extracted from a reading passage in each session. The passages were manipulated by TE techniques (i.e., underlining and boldfacing) and IF. Moreover, the number of tokens of the target collocations was increased to raise the participants' awareness. The total number of target structures was twice the number of target structures appeared in the passages for the output group. The participants worked in groups of two or three. After the teacher explained the meaning of the target collocations, the participants were directed to answer the questions related to the reading. Then, the L2 collocations taught in that session were reviewed. In the output group, the teacher presented the participants with the target collocations and then participants were required to make sentences with those collocations. At the end of each session, the collocations taught were reviewed. The control group, however, did not receive any particular instruction. The participants were simply given a reading passage. They could ask for their teacher's help in case they had problem understanding the meaning of the target collocations. Two days after the end of the treatment, the immediate posttest was administered to all groups. Two weeks after the end of the treatment, a delayed posttest was given to the participants.

\subsection{Data Analysis}

In order to determine whether input-based and output-based instructions had any effect on L2 collocational knowledge, the collected data were analyzed through mixed ANOVA, one-way ANOVA, and Tukey post hoc tests.

\section{Results}

Before embarking on choosing appropriate statistical test, it deemed necessary to test the normality of the data which was estimated through employing Shapiro-Wilk test of normality (Table 1). 
Table 1. Tests of Normality on Productive Collocation Tests

\begin{tabular}{|c|c|c|c|c|c|}
\hline & & & & iro- & \\
\hline Test Type & & Group & Statistic & $d f$ & Sig. \\
\hline \multirow{9}{*}{ Productive test } & \multirow[t]{3}{*}{ Pretest } & Control Group & .943 & 28 & .130 \\
\hline & & Input Group & .938 & 27 & .111 \\
\hline & & Output Group & .924 & 25 & .064 \\
\hline & \multirow[t]{3}{*}{ Immediate Posttest } & Control Group & .948 & 28 & .173 \\
\hline & & Input Group & .937 & 27 & .101 \\
\hline & & Output Group & .941 & 25 & .160 \\
\hline & \multirow[t]{3}{*}{ Delayed Posttest } & Control Group & 961 & 28 & .365 \\
\hline & & Input Group & .938 & 27 & .111 \\
\hline & & Output Group & .950 & 25 & .255 \\
\hline
\end{tabular}

As seen in Table 1, all significant values in Shapiro-Wilk tests were higher than confidence level of 0.05. This indicates that data were normally distributed. Table 2 displays the means and standard deviations of the participants' scores on the productive collocation tests.

Table 2. Descriptive Statistics of Productive Collocation Tests

\begin{tabular}{|c|c|c|c|c|c|}
\hline Test Type & & Group & $n$ & $M$ & $S D$ \\
\hline \multirow{9}{*}{ Productive test } & \multirow[t]{3}{*}{ Pretest } & Control Group & 28 & 2.21 & 1.228 \\
\hline & & Input Group & 27 & 2.22 & 1.281 \\
\hline & & Output Group & 25 & 2.28 & 1.242 \\
\hline & \multirow[t]{3}{*}{ Immediate Posttest } & Control Group & 28 & 9.89 & 1.499 \\
\hline & & Input Group & 27 & 13.89 & 1.396 \\
\hline & & Output Group & 25 & 13.04 & 2.508 \\
\hline & \multirow[t]{3}{*}{ Delayed Posttest } & Control Group & 28 & 7.14 & 3.088 \\
\hline & & Input Group & 27 & 10.81 & 3.247 \\
\hline & & Output Group & 25 & 11.24 & 2.241 \\
\hline
\end{tabular}

Table 2 shows the mean scores and standard deviations of the participants on the pretest in the control group $(M=2.21$, $S D=1.228)$, input group $(M=2.22, S D=1.281)$, and output group $(M=2.28, S D=1.242)$. Moreover, Table 2 depicts the mean scores and standard deviations of the participants on the immediate and delayed posttests in the control group $(M=9.89, S D=1.499)$,input group $(M=13.89, S D=1.396)$, and output group $(M=13.04, S D=2.508)$. The mean scores and standard deviations of the participants on the delayed posttest are also displayed: control group $(M=7.14$, $S D=3.088)$, input group $(M=10.81, S D=3.247)$, and output group $(M=11.24, S D=2.241)$. The input group had the highest mean score on the immediate posttest, whereas the output group had the highest mean score on the delayed posttest.

To answer the first research question, a mixed 3 x 3 ANOVA with two main factors, Time (i.e., receptive pretest, immediate posttest, and delayed posttest) and Group (i.e., control, input, and output) was conducted to examine whether there were significant interaction effects between groups. Moreover, a one-way ANOVA was conducted for the overall comparison of the three groups in terms of their scores on the pretest, immediate and delayed posttests along with posthoc Tukey tests. The confidence level was set at 0.05. Table 3 illustrates the results of mixed-ANOVA on the productive tests.

Table 3. Results of a Mixed-ANOVA on the Productive Tests with Time and Group Factors

\begin{tabular}{llllllll}
\hline Source & & Type III SS & MS & $d f$ & F & Sig. & Partial $\eta^{2}$ \\
\hline Between Subject & & & & & & & \\
& Group & 341.829 & 170.915 & 2 & 31.008 & .000 & .446 \\
& Error & 424.421 & 5.512 & 77 & & & \\
\hline Within Subject & & & & & & & .877 \\
& Time & 4345.417 & 2172.709 & 2 & 548.189 & .000 & .255 \\
& Time x Group & 177.707 & 44.427 & 4 & 11.209 & .000 & .200 \\
& Error (Time) & 610.368 & 3.963 & 154 & & & \\
\hline
\end{tabular}

Note. $\mathrm{SS}=$ sum of squares; $\mathrm{MS}=$ mean square

The results showed significant main effects of group $\left(\mathrm{F}_{2,77}=31.008, p=.000\right.$, partial $\left.\eta^{2}=.446\right)$. Moreover, there was a main effect for time $\left(\mathrm{F}_{2,154}=548.189, p=.000\right.$, partial $\left.\eta^{2}=.877\right)$. There was also a significant interaction between time and group $\left(\mathrm{F}_{2,154}=11.209, p=.000\right.$, partial $\left.\eta^{2}=.255\right)$. The partial eta squared also show very large effect sizes. Due to the significant main effect of group, a one-way ANOVA was performed for each test. Table 4 displays the results of one-way ANOVAs on the productive tests. 
Table 4. Results of One-Way ANOVAs on Productive Posttests

\begin{tabular}{lllllll}
\hline & & SS & $d f$ & MS & F & Sig. \\
\hline Pretest & Between Groups & .067 & 2 & .033 & .021 & .979 \\
& Within Groups & 120.421 & 77 & 1.564 & & \\
& Total & 120.487 & 79 & & & \\
\hline Immediate Posttest & Between Groups & 243.645 & 2 & 121.822 & 35.761 & $\mathbf{. 0 0 0}$ \\
& Within Groups & 262.305 & 77 & 3.407 & & \\
& Total & 505.950 & 79 & & & \\
\hline Delayed Posttest & Between Groups & 275.825 & 2 & 137.912 & 16.286 & $\mathbf{. 0 0 0}$ \\
& Within Groups & 652.063 & 77 & 8.468 & & \\
& Total & 927.887 & 79 & & & \\
& & & & &
\end{tabular}

No significant main effect of group was found in the pretest $\left(\mathrm{F}_{2,77}=.021, p=.979\right)$. However, a significant main effect of group was found in the immediate vocabulary test $\left(\mathrm{F}_{2,77}=35.761, p=.000\right)$ and the delayed posttest $\left(\mathrm{F}_{2,77}=16.286\right.$, $p=.000)$. Table 5 shows the results of Tukey post hoc analyses on the productive posttests.

Table 5. Results of Post hoc Tests on Productive Posttests

\begin{tabular}{lccccc}
\hline Dependent Variable & (I) Group & (J) Group & MD (I-J) & Std. Error & Sig. \\
\hline Immediate Posttest & Input & Control & 3.996 & .498 & $\mathbf{. 0 0 0}$ \\
& Output & Control & 3.147 & .508 & $\mathbf{. 0 0 0}$ \\
& Input & Output & .849 & .512 & .228 \\
\hline Delayed Posttest & Input & Control & 3.672 & .785 & $\mathbf{. 0 0 0}$ \\
& Output & Control & 4.097 & .801 & $\mathbf{. 0 0 0}$ \\
& Input & Output & -.425 & .808 & .859 \\
\hline
\end{tabular}

As depicted in Table 5, on the immediate posttest, both input and output groups scored significantly higher than the control group $(p=.000)$. However, there was no significant difference between input and output groups $(p=$ .228).Tukey post hoc analyses also revealed that on the delayed posttest, both input and output groups scored significantly higher than the control group $(p=.000)$. There was, however, no significant difference between input and output groups $(p=.859)$. Figure 1 shows the mean changes of scores on the productive tests across all groups over time. As displayed in Figure 1, the input group had the highest mean score in Time 2 (immediate posttest), whereas the output group had the highest mean score in Time 3 (delayed posttest). In Time 1 (pretest), however, the mean scores were very close to each other.

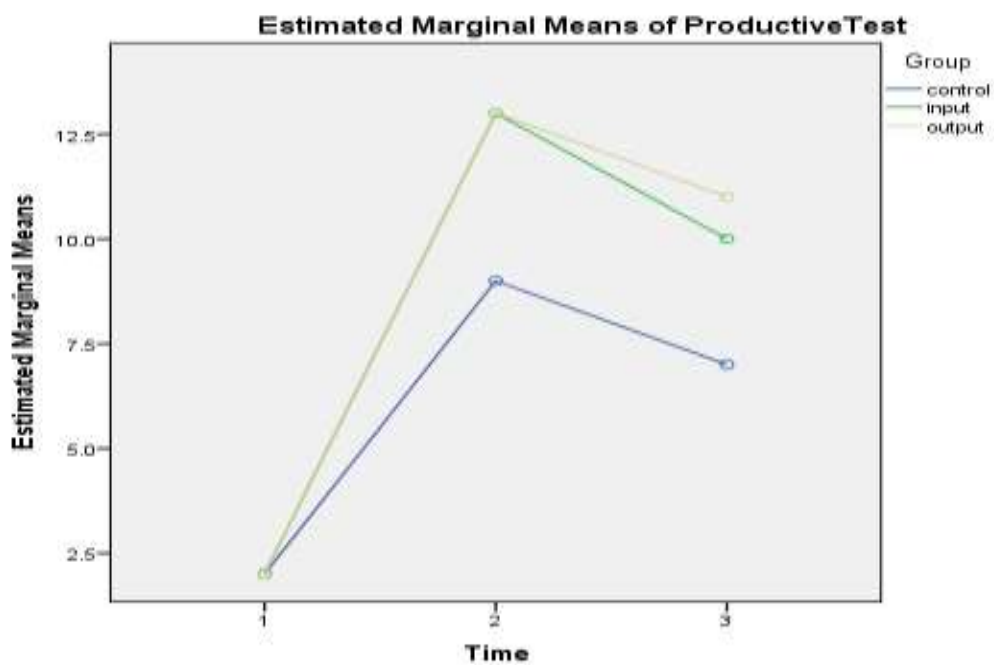

Figure 1. Mean Changes of Productive Posttests over Time

\section{Discussion and Conclusion}

The results showed that the input and output groups significantly outperformed the control group on the productive posttests. However, there were no significant differences between the input and output groups on the posttests. The results revealed that both input-based and output-based instructions can help EFL learners develop their productive collocational knowledge. The results are line with Fahim and Vaezi (2011) who found that TE, as an input-based technique, had significant effects on learning L2 collocations. The results further confirm the findings of Szudarski and Carter's (2016) study where IF combined with TE technique was found to be effective in L2 collocation learning in an EFL context. In fact, making input more salient through TE and IF techniques can foster the L2 learners' awareness which is viewed as a key factor in language learning (White, 1998). The findings are also in line with the notion that using the increased tokens of input (i.e., input flood) can attract learners' attention to the target forms (Reinders \& Ellis, 
2009). Attention is "the necessary and sufficient condition for the conversion of input into intake" (Schmidt, 1993, p. 209). In this study, the input group outperformed the control group in both immediate and delayed posttests. Another explanation for the results comes from the works of Smith (1991), who is the originator of input enhancement. Smith (1991) argued that "the most obvious way to try to affect the subconscious processes beneficially is by making relevant evidence in the input especially salient" (p.178). Therefore, it can be claimed that the findings of this study lend support to Smith's assumptions (1991) that input enhancement has a positive effect on the rate of L2 acquisition.

However, the results of this study are in contrast with Asaei and Rezvani (2015) who found that there is a significant difference between the input-based and output-based instructions in productive collocational knowledge of Iranian EFL learners $(p=.000<.05)$. The findings of the study are also in contrast with the Ellis' (2003) claim that output-based instruction could better improve the productive collocational knowledge of L2 learners in the long-term compared with input-based instruction. Although, in this study, there was a slight difference between the output and input groups, no significant difference was found in the long-term retention of the L2 collocations.

This study examined the effect of input-based and output-based instructions on L2 productive knowledge of collocations. The results also revealed the significant effects of input-based and output-based instructions on enhancing the recall and retention of L2 collocations. The results of this study are mainly conducive to EFL learners who specifically intend to improve their collocational knowledge. The results of the study may have some pedagogical implications for ESL/EFL practitioners as well. Input-based and output-based instructions can help teachers employ effective techniques to raise the L2 learners' awareness and consciousness. Moreover, EFL/ESL teachers can make the teaching collocations more helpful by using TE or IF techniques. In addition, input-based and output-based instructions can be applied to other language skills.

This study has some limitations which can be considered in future research. First, the sample was limited to senior high school students who were at lower-intermediate level. Therefore, future studies can be done on learners at other proficiency levels (i.e., elementary, upper-intermediate and advanced). Second, future studies can include other instructional approaches to teaching L2 collocations, e.g. process-based instruction. Third, in this study, five L2 collocations were included in each passage. Thus, choosing a text with different lexical coverage may produce different results. Finally, future studies are essential in which the immediate and delayed posttests are conducted at different time intervals to show the effect of input-based and output-based instructions on recall and retention of L2 collocations.

\section{References}

Allan, D. (2004). Oxford Placement Test. Oxford, UK: Oxford University Press.

Asaei, R., \& Rezvani, E. (2015). The effect of explicit vs. implicit instruction on Iranian EFL learners' use of collocations in L2 writing. Journal of Applied Linguistics and Language Research, 2(3), 1-22.

Benson, M. (1985). Collocations and idioms. In R. Ilson (Ed.), Dictionaries, Lexicography and Language Learning (pp. 61-68). Oxford: Pergamon Press.

Ellis, R. (2003). Task-based language learning and teaching. Oxford: Oxford University Press.

Ellis, R. (2012). Language teaching research and language pedagogy. Oxford: Wiley Blackwell.

Fahim, M., \& Vaezi, R. (2011). Investigating the effect of visually-enhanced input on the acquisition of lexical collocations by Iranian intermediate EFL learners: A case of verb-noun lexical collocations. Journal of Language Teaching and Research, 2(3), 552-560.

Hill, J. (2000). Revising priorities: From grammatical failure to collocational success. In M. Lewis (Ed.), Teaching collocation: Further developments in the lexical approach. London: Heinle Cengage Learning.

Laufer, B., \& Nation, P. (1999). A vocabulary-size test of controlled productive ability, Language Testing, 16(1), 33-51.

Laufer, B., \& Waldman, T. (2011). Verb-noun collocations in second language writing: A corpus analysis of learners' English. Language Learning, 61(2), 647-672.

Lewis, M. (ed.) (2000). Teaching collocation. Hove: Language Teaching Publications.

McCarthy, M., \& O’Dell, F. (2006). English collocations in use: How words work together for fluent and natural English; self-study and classroom use. Cambridge: Cambridge University Press.

Milton, J. (2009). Measuring second language vocabulary acquisition. Bristol, England: Multilingual Matters.

Moradi, M., \& Farvardin, M. T. (2016). A comparative study of effects of input-based, meaning-based output, and traditional instructions on EFL learners' grammar learning. Research in Applied Linguistics, 7(2), 99-119.

Nesselhauf, N. (2005). Collocations in a learner corpus. Amsterdam: John Benjamin's Publishing.

Reinders, H., \& Ellis, R. (2009). The effects of two types of input on intake and the acquisition of implicit and explicit knowledge. In R. Ellis et al. (Eds.), Implicit and explicit knowledge in second language learning testing and teaching (pp. 282-302). Bristol: Multilingual Matters.

Schmidt, R. (2001). Attention. In P. Robinson (Ed.), Cognition and second language instruction (pp. 3-32). Cambridge: Cambridge University Press. 
Shintani, N. (2015). The effectiveness of processing instruction and production-based instruction on L2 grammar acquisition: A meta-analysis. Applied Linguistics, 36(3), 306-325.

Smith, M. S. (1991). Speaking to many minds: On the relevance of different types of language information for the L2 learner. Second Language Research, 7(2), 118-132.

Swain, M. (1995). Three functions of output in second language learning. In G. Cook \& B. Seidlhofer (Eds.), Principle and practice in applied linguistics: Studies in honor of H. G. Widdowson (pp. 125-144). Oxford: Oxford University Press.

Swain, M. (2000). The output hypothesis and beyond: Mediating acquisition through collaborative dialogue. In Lantolf (Ed.), Sociocultural theory and second language learning (pp. 97-114). Oxford: Oxford University Press.

Swain, M. (2005). The output hypothesis: theory and research. In E. Hinkel (Ed.), Handbook of research in second language teaching and learning (pp. 471-483). Mahwa, NJ: Lawrence Erlbaum.

Swain, M., \& Lapkin, S. (1995). Problems in output and the cognitive processes they generate: A step towards second language learning. Applied linguistics, 16(3), 371-391.

Szudarski, P., \& Carter, R. (2016). The role of input flood and input enhancement in EFL learners' acquisition of collocations. International Journal of Applied Linguistics, 26(2), 245-265.

Toth, B. (2006). Processing instruction and a role for output in second language acquisition. Language learning, 56(2), 319-385.

White, J. (1998). Getting the learners' attention: A typographical input enhancement study. In C. Doughty \& J. Williams (Eds.), Focus on form in classroom second language acquisition (pp. 85-113). New York: Cambridge University Press.

\section{Appendix A}

\section{List of Collocations}

\begin{tabular}{|l|l|l|}
\hline -nuclear families & -rival company & - put up a fight \\
-late husband/wife & -add an extension & -gain/get a place \\
-trial separation & -cut-throat competition & -come up against fierce competition \\
-bitter divorce & -balance the budget & -achieve one's ambitions \\
-broken home & -put in a bid & -score a goal \\
-confirmed bachelor & -deserve to win & \\
-affordable housing & -narrowly defeated/beaten & \\
-take out mortgage & & \\
\hline
\end{tabular}

\section{Appendix B}

\section{Productive Test}

Complete the collocations. You are given the first letter of the missing words.

1. Most families in China are n.......... families because they have only one child.

2. My uncle was a c......... bachelor, lived with us in my grandparents' home.

3. My $1 . . . . . .$. wife, who died two years ago, was in her twenties.

4. My grandma used to say that it is not fair on children to let them grow up in b....... homes.

5. They were happy to win their last match at 6:00; the opposing team, put up a good f...... .

6. All players want to win the match as they try to a........ their ambitions.

7. Manchester has now g...... a place in the next stage of the competition.

8. They will undoubtedly come up against some fierce c..........

9. Despite severe competition, Jane $\mathrm{p} . . . .$. in a bid which was more attractive than anything.

10 . We've put in a very c........... competition, so I hope we'll get the job.

11. It's my job to b.......... the budget.

12. Sometimes, a team or players train hard, but gets $n . . . \ldots \ldots \ldots$ defeated.

13. I have to buy a new apartment, but there's a shortage of a......... Housing here.

14. She had to t........ out a big mortgage as the house was very expensive.

15. Some sports people d.......... to win the match.

16. All players try to play well in a match. The aim is to $\mathrm{s} . . . . . .$. a goal

17. Mary had a b......... divorce since she herself grew up her little children.

18. Jack and his wife may be having a t........... separation and may eventually decide to get a divorce.

19. If you want to a......... an extension, there is a room for it.

20. Nike brand is the r.......... company of Adidas. 
Appendix C

\section{Sample Reading for the Input Group \\ Family Relationships}

Sociologists talk about nuclear and extended families. A nuclear family is just parents and children. An extended family is a wider network including grandparents, cousins, etc. Someone's late husband/ wife is one who has died. An estranged husband/ wife is one who lives in a different place and has a difficult relationship with their husband/ wife. They may be having a trial separation and may eventually decide to get a divorce. In some cases it can be a bitter divorce.

Recent studies show that people are having fewer and fewer children. World population numbers will begin to decline. In Europe, for example, there are a lot of nuclear families with only one or two children, while they might have had three or four children in the past and they were extended families; even they were living with a confirmed bachelor. In fact, in China, the problem is worse. Most young Chinese adults have no brothers or sisters and face the idea of having to care for two parents. In such a condition, if one of couples dies or an estranged husband/wife wants to live in a different home and couples will have a trial separation and after that, they want to get a divorce. It will be a bitter divorce and an ex-husband/wife will not have a good feeling. So children are not in a stable home and they will live in a broken home. 